\title{
Lake Evaporation in a Hyper-Arid Environment, Northwest of China-Measurement and Estimation
}

\author{
Xiao Liu ${ }^{1,2}$, Jingjie Yu ${ }^{1,2, *}$, Ping Wang ${ }^{1}$, Yichi Zhang ${ }^{1}$ and Chaoyang Du ${ }^{1,2}$ \\ 1 Key Laboratory of Water Cycle \& Related Land Surface Processes, Institute of Geographic Sciences and \\ Natural Resources Research, Chinese Academy of Sciences, 11A, Datun Road, Chaoyang District, \\ Beijing 100101, China; liux.13b@igsnrr.ac.cn (X.L.); wangping@igsnrr.ac.cn (P.W.); \\ zhangych@lreis.ac.cn (Y.Z.); ducy.12b@igsnrr.ac.cn (C.D.) \\ 2 University of Chinese Academy of Sciences, Beijing 100049, China \\ * Correspondence: yujj@igsnrr.ac.cn; Tel.: +86-10-6488-9308 \\ Academic Editor: Y. Jun Xu \\ Received: 26 September 2016; Accepted: 7 November 2016; Published: 12 November 2016
}

\begin{abstract}
Lake evaporation is a critical component of the hydrological cycle. Quantifying lake evaporation in hyper-arid regions by measurement and estimation can both provide reliable potential evaporation $\left(\mathrm{ET}_{0}\right)$ reference and promote a deeper understanding of the regional hydrological process and its response towards changing climate. We placed a floating E601 evaporation pan on East Juyan Lake, which is representative of arid regions' terminal lakes, to measure daily evaporation and conducted simultaneous bankside synoptic observation during the growing season of 2013-2015. A semi-empirical evaporation model derived from Dalton model was parameterized and validated with measured data. The model was then used to estimate lake evaporation during 2002-2015. According to in situ measurements, maximum, minimum and mean lake evaporation were 8.1, 3.7 and $6.5 \mathrm{~mm} /$ day, and growing season evaporation was $1183.3 \mathrm{~mm}(\sim 80 \%$ of the annual amount). Adding up non-growing season evaporation that we converted from $\$ 20$ pan evaporation at Ejina weather station, the annual mean lake evaporation, $1471.3 \mathrm{~mm}$, was representative of lower Heihe River's $\mathrm{ET}_{0}$. Model inter-comparison implied our model performed well both in simplicity and accuracy and has potential utilization in a data-sparse area. In 2002-2015, estimated mean daily evaporation was $6.5 \mathrm{~mm} /$ day and growing season evaporation was $1233.7 \mathrm{~mm}$. Trend analysis of estimated evaporation proved the evaporation paradox's existence in this hyper-arid region and validated complementary relationship theory's adaptability.
\end{abstract}

Keywords: lake evaporation measurement; evaporation model; floating E601 evaporation pan; lake evaporation time series; Lower Heihe River; East Juyan Lake

\section{Introduction}

Evaporation links the atmosphere and land surface system in the hydrological cycle [1-3]. Water loss from evaporation is recognized as the largest component of the regional hydrological cycle in arid regions, especially for lakes or reservoirs [4-6]. Open water evaporation, which includes lake evaporation, can also represent regional potential evaporation (PET) [7] and is often used as an important parameter in many methods to estimate terrestrial evapotranspiration (ET) [8-10]. However, in remote areas, it is difficult to conduct in situ measurement to obtain reliable evaporation data due to tough conditions; many ET studies have thus been based on empirical or estimated values rather than measured PET data-an approximation that increases uncertainty and has some limitations [11-16]. Quantifying evaporation is important for hydrological research on groundwater modeling and large-scale hydrological cycle simulation, and also helps us gain a better understanding of hydrological responses to climate change in extreme weather conditions [17-19]. Thus, it is critical 
to provide fundamental and reliable open water evaporation reference for relevant ET research in validation, improvement of remote sensing methods to estimate ET, and seeking for practical methods for open water evaporation estimation in arid regions.

In situ measurement and model estimation are two main approaches for quantifying open water evaporation. The in situ measurement method originated in E. Halley's research in 1687, and different types of measuring instruments were subsequently developed in the following studies [20-22]. The World Meteorological Organization suggests the following as standard equipment for measuring open water evaporation [23]: a $20 \mathrm{~m}^{2}$ evaporation tank, a GGI-3000 from the Soviet Union [24,25], and a Class A evaporator from the USA [22,26-28]. The $20 \mathrm{~m}^{2}$ evaporation tank is found only at some evaporation stations due to high expenses in building and maintaining the equipment, whereas the GGI-3000 is found only in former Soviet Union (FSU) countries, Russia and China [29]. Compared with the evaporation pans previously mentioned, the E601 evaporation pan (i.e., modified GGI-3000 pan) is practical, cost-effective and commonly used by Chinese researchers [10,30-35]. One of the characteristics of the E601 pan is that it has four arc water troughs $20 \mathrm{~cm}$ wide, which comprise a water circle to reduce the effects of turbulence generated by the pan (particularly by the rim of the pan) while ensuring accuracy [29,36]. However, for convenience and simplicity, researchers often locate the E601 pan on land rather than on the water, which may inaccurately represent open water evaporation due to different underlying conditions; therefore, evaporation data collected in this way must be converted to actual open water evaporation using a coefficient, which increases uncertainty in measured data $[15,16,29]$. Researchers also applied the eddy covariance (EC) method, which is theoretically based on the correlation of vertical wind speed and air moisture content fluctuation and an accurate way to measure open water evaporation with fine accuracy [37-43]. Although the EC method and pan method can both provide convincing and reasonable lake evaporation data $[41,44]$, we cannot ignore that in a remote area with tough residence conditions, it is very hard to carry out in situ experiments, especially since EC equipment's durability and reliability may be affected by the extreme temperature (up to $41{ }^{\circ} \mathrm{C}$ and down to $-36{ }^{\circ} \mathrm{C}$ ) and strong wind (up to $16.5 \mathrm{~m} / \mathrm{s}$ ) in this hyper-arid study area [10], while the E601 pan, with three modifications, can meet our need of obtaining the actual lake evaporation with satisfying adaptability and affordable cost. Another approach for quantifying lake evaporation is model estimation; many studies have shown the reliability and practicality of this method, including the Dalton model [45], Bowen ratio-energy balance (BREB) method [46], Penman model [47], Priestley-Taylor model [48], water budget method [49], complementary relationship method [50-52] and energy balance method [53,54], etc. Table 1 shows a summary of relevant literature on open water evaporation researches with measurement and estimation methods $[4,7,9,41,53,55-60]$.

As discussed above, the modified floating E601 pan measurement is a more adaptive, reliable and affordable method to reveal actual lake evaporation in remote and tough areas compared with the EC method. Moreover, the floating E601 evaporation pan on the lake behaves better in revealing actual lake evaporation than evaporation pans on land $[10,28,57]$. However, in extreme weather conditions (i.e., extreme dryness, hotness and coldness, or very high wind speed), due to the complexity and difficulty in instrument maintenance, this method is rarely used and it is not suitable for long-term in situ measurement. Meanwhile, evaporation models require a great deal of input data, which limits its utility in data-sparse regions. Concerned with such shortcomings, in this study, we directly measured daily lake evaporation using a floating E601 pan on the lake for the first time and sought a practical and low-input evaporation model to quantify open water evaporation in hyper-arid regions (Aridity Index $<0.05, \mathrm{AI}=\mathrm{P} / \mathrm{PET}$ and $\mathrm{P}$ is mean annual precipitation [61]), taking East Juyan Lake (EJL) as an example, which is located in Ejina Delta, a hyper-arid and remote region in the northwest of China. We also obtained long time series of lake evaporation and added solid and more convincing proof of the evaporation paradox's existence in this region. 
Table 1. Summary of relevant literature on open water evaporation studies based on in situ measurement or model estimation (the current paper is added for completeness).

\begin{tabular}{|c|c|c|c|}
\hline Study & Physical and Climate Settings/Site & Method/Highlights & Key Results \\
\hline $\begin{array}{l}\text { Sturrock } \\
\text { et al. (1992) }\end{array}$ & $\begin{array}{l}\text { Williams Lake in Minnesota, USA; } \\
0.36 \mathrm{~km}^{2} ; \text { mean depth of } 5.2 \mathrm{~m} ; \\
\text { within the continental climate of } \\
\text { North America. }\end{array}$ & $\begin{array}{l}\text { Energy budget method; land and raft weather } \\
\text { stations are used; each energy budget } \\
\text { component is measured or calculated. }\end{array}$ & $\begin{array}{l}\text { 1. Seasonal evaporation rate varied from } 2.19 \mathrm{~mm} / \text { day to } 2.82 \mathrm{~mm} / \text { day. } \\
\text { 2. Energy budget values of evaporation varied from }+13 \% \text { to }-11 \% \text { of mass transfer values. } \\
\text { 3. Large differences exist in the magnitudes of energy budget components, with solar radiation } \\
\text { being the greatest and advection the smallest. }\end{array}$ \\
\hline $\begin{array}{l}\text { Winter } \\
\text { et al. (1995) }\end{array}$ & Williams Lake in Minnesota, USA. & $\begin{array}{l}11 \text { lake evaporation methods are evaluated; } \\
\text { Data are obtained on a raft, bankside and a } \\
\text { station } 60 \mathrm{~km} \text { away. }\end{array}$ & $\begin{array}{l}\text { 1. Modified DeBruin-Keijman, Priestley-Taylor and Penman equation estimated monthly } \\
\text { evaporation that agreed most closely with energy budget values. } \\
\text { 2. Input data measured near the lake is essential to apply these methods, and if only distant data } \\
\text { are available, Jensen-Haise and Makkink methods are preferable. }\end{array}$ \\
\hline $\begin{array}{l}\text { Valiantzas } \\
\text { (2006) }\end{array}$ & $\begin{array}{l}\text { A weather station called } \\
\text { Patrai in Greece. }\end{array}$ & $\begin{array}{l}\text { Penman equation; Approximation of the } \\
\text { equation's components enables easy estimation } \\
\text { of evaporation with basic data. }\end{array}$ & $\begin{array}{l}\text { 1. Penman equation is simplified for routine hydrologic applications and a more simplified version } \\
\text { without wind speed is given and tested. } \\
\text { 2. The new open water evaporation formulas were adapted for calculating reference crop ET. }\end{array}$ \\
\hline $\begin{array}{l}\text { Rosenberry } \\
\text { et al. (2007) }\end{array}$ & $\begin{array}{l}\text { Mirror Lake in New Hampshire, USA; } \\
0.15 \mathrm{~km}^{2} \text {; annual precipitation and } \\
\text { evaporation is } 1220 \text { and } 490 \mathrm{~mm} .\end{array}$ & $\begin{array}{l}15 \text { evaporation methods are applied; BREB } \\
\text { method is chosen as the standard; In situ } \\
\text { measured data are used. }\end{array}$ & $\begin{array}{l}\text { 1. Priestley-Taylor, deBruin-Keijman and Penman method values compared most favorably with } \\
\text { BREB's (within } 20 \% \text { difference). } \\
\text { 2. Methods may be unduly sensitive to wind speed, when wind speed is neither substantially } \\
\text { larger nor smaller. } \\
\text { 3. Temperature-only methods compared remarkably well with BREB values. } \\
\text { 4. Results of this research also serve well in other lakes with a similar physical and climatic setting. }\end{array}$ \\
\hline $\begin{array}{l}\text { Masoner } \\
\text { et al. (2008) }\end{array}$ & $\begin{array}{l}\text { In a wetland at the U.S. Geological } \\
\text { Survey Norman Landfill Research Site } \\
\text { in Oklahoma, USA; an area of } 8800 \mathrm{~m}^{2} \text {. }\end{array}$ & $\begin{array}{l}\text { In situ measurement; Monthly evaporation } \\
\text { data from Class A pan and floating pan } \\
\text { are used. }\end{array}$ & $\begin{array}{l}\text { 1. Floating pan can better simulate actual physical conditions on the water surface than } \\
\text { evaporation pan on land. } \\
\text { 2. Floating pan to land pan ratios varied in different months, ranging from } 0.69 \text { to } 0.87 \text {. }\end{array}$ \\
\hline $\begin{array}{l}\text { Vercauteren } \\
\text { et al. (2009) }\end{array}$ & $\begin{array}{l}\text { Lake Geneva (LG) in Switzerland; } \\
582 \mathrm{~km}^{2} ; \text { wind speed was } \\
\text { smaller than } 10 \mathrm{~m} / \mathrm{s} \text { and waves rarely } \\
\text { exceeded } 20 \mathrm{~cm} .\end{array}$ & $\begin{array}{l}\text { Bowen ratio; sensible heat }(\mathrm{H}) \text { and basic } \\
\text { synoptic data are used; Eddy covariance } \\
\text { method is used. }\end{array}$ & $\begin{array}{l}\text { 1. A new method to estimate wet surface evaporation using easily obtained data was proposed } \\
\text { based on Bowen ratio equation, avoiding the term of } G \text { in the energy budget that is hard to } \\
\text { measure on wet surfaces. } \\
\text { 2. Validation by eddy covariance values indicated excellent accuracy when applied to LG. }\end{array}$ \\
\hline $\begin{array}{l}\text { Granger and } \\
\text { Hedstrom (2011) }\end{array}$ & $\begin{array}{l}\text { Three lakes with fetch distances ranging } \\
\text { from } 150 \mathrm{~m} \text { to } 11,000 \mathrm{~m} \text { in Canada. }\end{array}$ & $\begin{array}{l}\text { Direct measurement of eddy covariance } \\
\text { method; wind speed, air temperature and } \\
\text { humidity data are measured on the lake. }\end{array}$ & $\begin{array}{l}\text { 1. Wind speed is the most significant factor governing lake evaporation, followed by land-water } \\
\text { contrast of temperature and vapor pressure, while net radiation bears no relationship with lake } \\
\text { evaporation in short time periods. } \\
\text { 2. Relationships were developed between the hourly rates of lake evaporation and the following } \\
\text { significant variables and parameters, and a versatile model for estimating hourly lake evaporation } \\
\text { rate is proposed with good accuracy. }\end{array}$ \\
\hline
\end{tabular}


Table 1. Cont.

\begin{tabular}{|c|c|c|c|}
\hline Study & Physical and Climate Settings/Site & Method/Highlights & Key Results \\
\hline $\begin{array}{l}\text { McGloin } \\
\text { et al. (2014) }\end{array}$ & $\begin{array}{l}\text { A reservoir in southeast Queensland, } \\
\text { Australia; } 0.17 \mathrm{~km}^{2} \text {; seasonal } \\
\text { subtropical climate. }\end{array}$ & $\begin{array}{l}\text { Floating weather station; hourly latent flux } \\
\text { measured by eddy covariance; Mass transfer } \\
\text { method; the hydrodynamics model-DYRESM. }\end{array}$ & $\begin{array}{l}\text { 1. Various modelling methods were used to estimate hourly latent heat fluxes and the theoretical } \\
\text { mass transfer model performed the best, the Granger and Hedstrom the worst. } \\
\text { 2. Estimates by the DYRESM model tended to be greater than measured values. } \\
\text { 3. Improvements can be made to the traditional mass transfer and DYRESM models for many } \\
\text { applications, including modelling the effects small lakes have on regional weather. }\end{array}$ \\
\hline $\begin{array}{l}\text { Shilo } \\
\text { et al. (2015) }\end{array}$ & $\begin{array}{l}\text { Lake Kinneret in northern Israel; } \\
168.7 \mathrm{~km}^{2} \text {; annual evaporation } \\
\text { of } 1400 \mathrm{~mm} \text {. }\end{array}$ & $\begin{array}{l}\text { Aerodynamic method and energy balance } \\
\text { method; Synoptic factors are measured at the } \\
\text { station located near the center of the lake. }\end{array}$ & $\begin{array}{l}\text { 1. The primary factors determining lake evaporation are solar radiation, near surface air and water } \\
\text { temperatures, relative humidity, wind speed and near surface atmospheric stability. } \\
\text { 2. Lake evaporation during exceptionally hot summer days was lower than normal when wind } \\
\text { speed was much lower. } \\
\text { 3. The weakening of the permanent synoptic Etesian winds and the descent of the marine } \\
\text { inversion to a height of the topographic ridge are responsible for the reduction of the } \\
\text { Mediterranean Sea Breeze and evaporation. }\end{array}$ \\
\hline $\begin{array}{l}\text { Ma } \\
\text { et al. (2016) }\end{array}$ & $\begin{array}{l}\text { Nam Co Lake in the Tibetan Plateau; } \\
\text { closed, semi-brackish lake; } 2013 \mathrm{~km}^{2} ; \\
\text { a semi-arid sub-frigid monsoon climate. }\end{array}$ & $\begin{array}{l}\text { The China Meteorological Forcing Dataset was } \\
\text { used; E601 pan evaporation data was used to } \\
\text { compare with CRLE model estimations } \\
\text { without wind speed data. }\end{array}$ & $\begin{array}{l}\text { 1. The complementary relationship lake evaporation (CRLE) model behaved well in Nam Co Lake } \\
\text { without wind speed input, but implicitly considered the wind effect via vapor transfer coefficient. } \\
\text { 2. From } 1979 \text { to } 2012 \text {, the mean annual evaporation of Nam Co Lake is } 635 \mathrm{~mm} \text {, and the annual } \\
\text { evaporation of Nam Co Lake expressed a very slight decreasing trend. } \\
\text { 3. Evaporation decreasing was responsible for } 4 \% \text { of recent rapid Nam Co Lake expansion. }\end{array}$ \\
\hline $\begin{array}{l}\text { Liu } \\
\text { et al. (2016) }\end{array}$ & $\begin{array}{l}\text { East Juyan Lake, northwestern China; } \\
40 \mathrm{~km}^{2} \text {; in the hyper-arid region with } \\
\mathrm{ET}_{0}>1400 \mathrm{~mm} \text { and annual P } \\
\text { of } 36.6 \mathrm{~mm} \text {. }\end{array}$ & $\begin{array}{l}\text { Floating E601 pan; bankside weather station; } \\
\text { a semi-empirical daily lake evaporation model } \\
\text { is proposed. }\end{array}$ & $\begin{array}{l}\text { 1. Total lake evaporation during the growing season was } 1183.3 \mathrm{~mm} \text { according to the floating } \\
\text { evaporation pan on } \mathrm{EJL}, \text { with the max, min and mean daily } \mathrm{E} \text { of } 8.1,3.7 \text { and } 6.5 \mathrm{~mm} \text {, respectively. } \\
\text { 2. A new daily lake evaporation model, derived from Dalton model, was proposed with simple } \\
\text { inputs ( } T_{a}, u \text { and } R H \text { ) but moderate modeling accuracy. } \\
\text { 3. The lower Heihe River's } \mathrm{ET}_{0} \text { represented by annual open water evaporation was } 1471.3 \mathrm{~mm} \text {. } \\
\text { 4. Trend analysis of estimated evaporation proved evaporation paradox's existence in this } \\
\text { hyper-arid region and validated the complementary relationship theory's adaptability. }\end{array}$ \\
\hline
\end{tabular}


In this research, we plan to utilize the in situ measurement method and propose a daily lake evaporation model with bankside synoptic data to measure as well as estimate the daily evaporation of EJL during the growing season (ice-free, from April to September) by three steps: (1) obtaining daily evaporation data of EJL from the floating E601 evaporation pan; (2) establishing a daily lake evaporation model for EJL with measured synoptic data; and (3) utilizing the proposed method to estimate EJL's daily evaporation during 2002-2015.

\section{Materials and Methods}

\subsection{Study Area}

East Juyan Lake $\left(101^{\circ} 11^{\prime} 31^{\prime \prime}-101^{\circ} 19^{\prime} 07^{\prime \prime} \mathrm{E}, 42^{\circ} 15^{\prime} 25^{\prime \prime}-42^{\circ} 20^{\prime} 00^{\prime \prime} \mathrm{N}\right)$ is located $\sim 60 \mathrm{~km}$ north of Ejina weather station, which is a hyper-arid region in the lower reach of the Heihe River-the second largest inland river in northwest China. Ejina Delta is characterized by a continental climate that is extremely hot in the summer and cold in the winter. The maximum daily temperature was $41{ }^{\circ} \mathrm{C}$ (in July) and the minimum daily temperature was $-36^{\circ} \mathrm{C}$ (in January). There are strong winds, especially in spring and autumn, with maximum wind speed of $16.5 \mathrm{~m} / \mathrm{s}$ [62-64]. According to data from the Ejina weather station from 1959 to 2015, the mean annual temperature, precipitation, pan evaporation, relative humidity and wind speed were $9.0^{\circ} \mathrm{C}, 36.6 \mathrm{~mm}, 3755 \mathrm{~mm}(\phi 20$ evaporation pan, which is a copper pan with a diameter of $20 \mathrm{~cm}$ and height of $10 \mathrm{~cm}$ ), $33.7 \%$ and $3.3 \mathrm{~m} / \mathrm{s}$, respectively. The growing season in the delta is from April to September, during which time it is ice free. Ejina Delta' s dominant landscape is the Gobi Desert (Figure 1), with seasonal runoff in the east river and west river $[65,66]$.

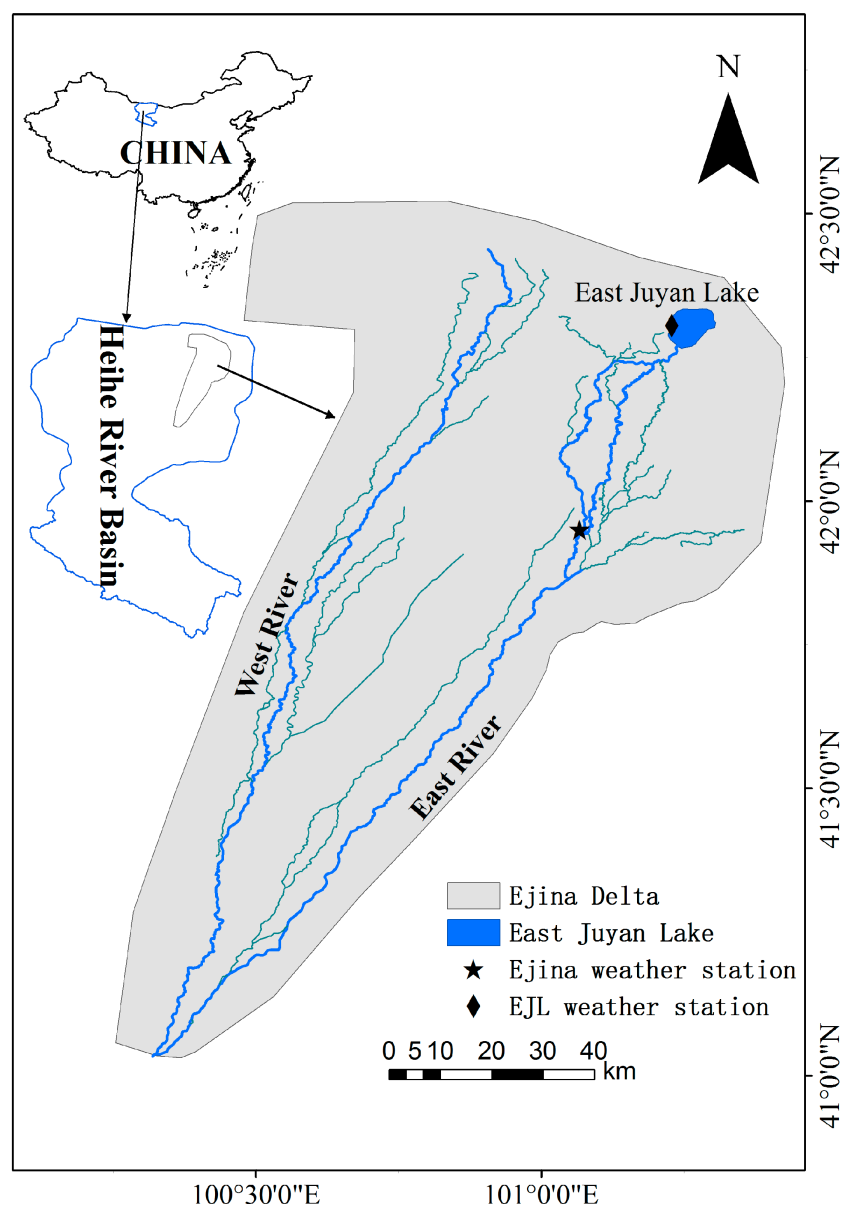

Figure 1. Location of the Ejina Delta and East Juyan Lake. 
EJL, surrounded by the Gobi Desert, is a shallow lake lying at the end of the east river with the mean water depth of $1.8 \mathrm{~m}$. According to remote sensing data, the mean area of EJL during the past decade was $\sim 40 \mathrm{~km}^{2}$, with a maximum area of $59.6 \mathrm{~km}^{2}$ [13]. It must be noted that EJL dried up in 1992 due to decreasing river runoff in the lower Heihe River [67,68]. Since 2002, EJL has been recharged under the official ecological water conveyance project (EWCP), which was launched to transport water from the upper and middle reaches of the Heihe River to the lower reach-Ejina Delta-to mitigate ecological problems such as lake shrinkage, groundwater decline and vegetation degradation in EJL and the associated riparian zone $[69,70]$. Annually, $\sim 45$ million $\mathrm{m}^{3}$ water is conveyed to EJL.

\subsection{Material}

\subsubsection{Data Sources}

In this study, synoptic data and evaporation data are used. Synoptic data includes data from the Ejina weather station and EJL bankside weather station that we have set up. Evaporation data includes E601 pan evaporation data at Ejina weather station (on land) and floating E601 pan evaporation on EJL.

The Ejina weather station is maintained by the local weather bureau and is $60 \mathrm{~km}$ away from EJL (Figure 1). Because data from this station may not reflect the actual climate conditions of the lake, we set up the East Juyan Lake bankside weather station $20 \mathrm{~m}$ away from the lake (Figure 2) to automatically observe precipitation, air temperature, wind speed (at $2 \mathrm{~m}$ ), relative humidity, solar radiation and atmospheric pressure in $5 \mathrm{~min}$ intervals. The data are transferred by the DTU (Data Transfer Unit) online in 60 min intervals. Daily synoptic data were auto-recorded from 25 August 2013 to 30 September 2015 in the growing season, except for occasional gaps due to equipment being out of order. Daily synoptic data from the Ejina weather station are thus available accordingly.

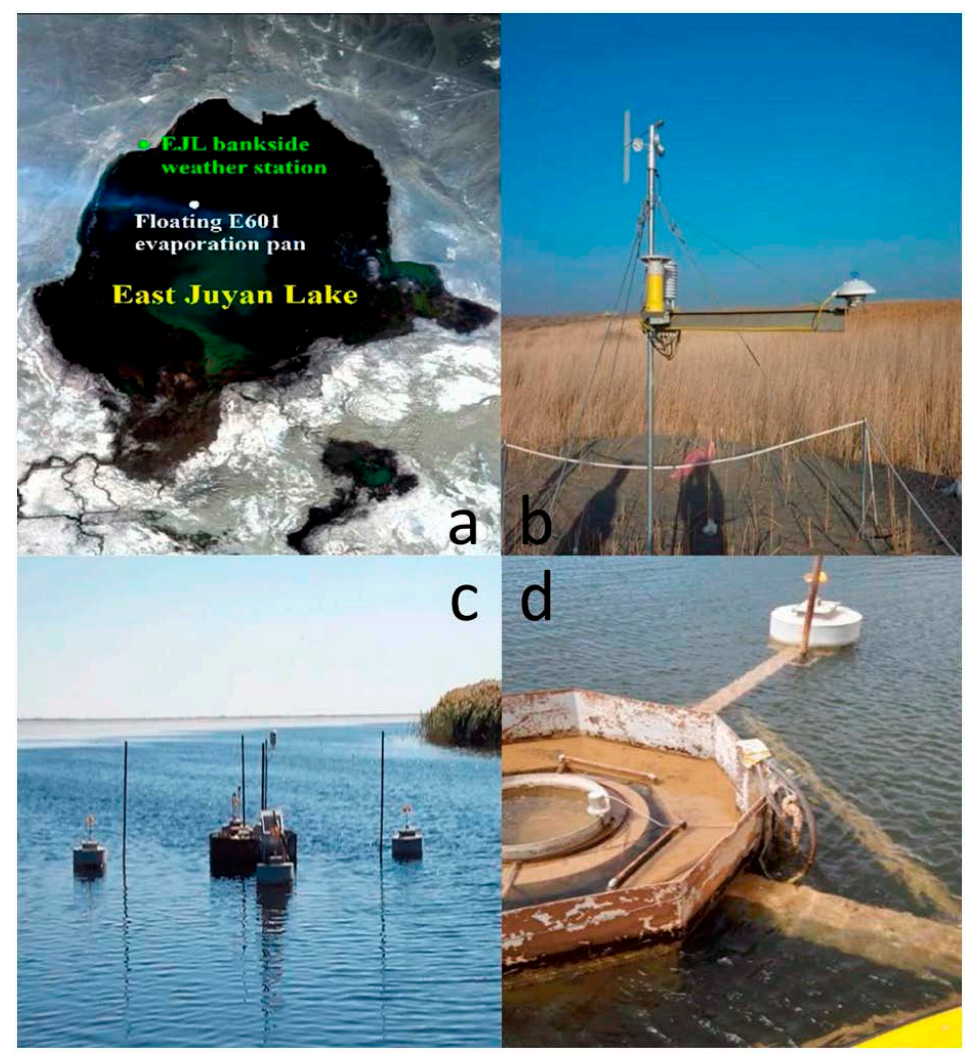

Figure 2. Image of East Juyan Lake (EJL) (a); EJL bankside weather station (b) and floating E601 evaporation pan $(\mathbf{c}, \mathbf{d})$. 
The evaporation data include E601 pan evaporation data from Ejina weather station from 2002 to 2015, and the floating E601 evaporation pan (Figure 2) from 25 August 2013 to 30 September 2015. The pan is located on the lake approximately $150 \mathrm{~m}$ away from the bank (minimum water depth $>1.2 \mathrm{~m}, 101^{\circ} 15^{\prime} 42^{\prime \prime} \mathrm{E}$ and $42^{\circ} 19^{\prime} 45^{\prime \prime} \mathrm{N}$ ) and was maintained weekly. The sensor can measure the water level of the E601 pan in 5 min intervals with $0.1 \mathrm{~mm}$ precision, and when the water level of the pan reaches a low value due to evaporation, the pump will automatically add water to maintain a reasonable water level (the distance between water surface to top of the pan's edge is less than $15 \mathrm{~cm}$ ). The floating E601 pan water level data from the sensor yielded 239 days of pan evaporation data (except for periods of ice or equipment's out of work).

\subsubsection{Data Quality Control}

In case of occasional strong wind and high waves, we have designed an anti-wave steel boat that can prevent pan inflow and water level fluctuation. The E601 pan is floating in the center of the boat with arms stretching out for $5 \mathrm{~m}$ in four directions, and the boat is fixed by four steel tubes in the lake to allow only vertical displacement, making the big boat a relatively steady platform whereby the water inside the boat is almost still and the water level data is hardly affected by high waves (Figure 2c). In addition, the E601 pan is floating on the water that is freely connected to the water outside of the boat. The pan is thus actually floating on the lake inside the boat and the steel plates ( $40 \mathrm{~cm}$ in height) around the main body of the boat. Due to a distance of $50 \mathrm{~cm}$ from the steel plate to the edge of the E601 pan, pan inflow can be effectively prevented (Figure 2d). For unpredicted wind and high waves, pan inflow can be identified and eliminated after quality control of processing high measuring frequency water level data. Such measures mentioned above can ensure the reliability of the pan evaporation data we obtained.

We calculated the daily evaporation by considering the starting time water level, the ending time water level, and the upward (water out of the pan) and downward (water into the pan) water level jump during a day. Water jump is caused by pumping water, occasional precipitation, splashed water etc., and can be easily identified with the help of water level data in high frequency ( 5 min steps), since water jump can be $0.3-0.8 \mathrm{~mm}$ within one or two time steps, whereas the evaporation rate scarcely exceeds $0.2 \mathrm{~mm}$ within $10 \mathrm{~min}$.

\subsection{Method}

\subsubsection{Brief Description of the E601 Pan}

The widely used E601 pan is made of fiber-reinforced polymer and is of cylindrical design with a surface area of $3000 \mathrm{~cm}^{2}$ and depth of $60 \mathrm{~cm}$. It is set in the soil with its rim $30 \mathrm{~cm}$ above the ground and with a cone-shaped or a cylindrical-shaped bottom, and there is a needle ruler attached at the rim of the pan to measure water level change caused by evaporation [71]. Apart from the identical designs and dimensions with GGI-3000 pans, there are two modifications in the E601 pan: (1) when installing, the E601 pan is supported $22.5 \mathrm{~cm}$ higher than the GGI-3000 pan, making the rim $30 \mathrm{~cm}$ above the ground; (2) there is a water ring around the pan consisting of four arc water troughs $20 \mathrm{~cm}$ in width, giving E601 pan the advantage of reducing the edge effects of turbulence generated by the rim of the pan over the Russian GGI-3000 pan [36].

E601 pan is a frequently used way to measure evaporation, despite its remaining shortcomings. In this study, concerned with the disadvantages of the traditional E601 pan, we made three major modifications:

(1) In order to have the pan in the lake rather than on land, we designed a big steel boat with four 5-m-long arms, placing the pan inside this boat's main body on the lake for less interference from waves (Figure 2d). Consequently, the measured pan evaporation is more representative of actual lake evaporation than data from evaporation pans on land; 
(2) We replaced the needle ruler with an auto-recorded water level sensor to measure evaporation, the sensor set at the rim is of high accuracy $(0.1 \mathrm{~mm}$ precision) and can record water level data automatically, avoiding errors caused during manual operation and reading, thereby, ensuring water level data accuracy;

(3) We also set up a pump that can automatically add water into the pan until it reaches a given water level at midnight, if the water was reduced to a certain level during the daily evaporation, thereby diminishing possible sudden heat changes from the added water during daytime and simplifying the measurement process.

In short, the evaporation pan we used can represent actual lake evaporation and ensure fine data accuracy without intensive maintenance during the experiment.

\subsubsection{Derivation of the Model}

Lake evaporation process is governed by a number of factors, and vapor pressure deficit (VPD), air temperature $\left(T_{a}\right)$ and wind speed $(u)$ are the three main synoptic factors [45,60,72]. Dalton's traditional method to estimate open water evaporation has low-input demand. However, after applying Dalton's equation to calculate EJL's daily evaporation, we found the calculation a little complicated and the modeling accuracy too low ( $R^{2}$ is below 0.5$)$. Thus, to improve Dalton method's modeling accuracy and adaptability, we derived a semi-empirical lake evaporation model based on the Dalton model, in which the original form can be expressed as:

$$
E=f(u) \cdot\left(e_{s}-e_{a}\right)
$$

where $E$ is the open water evaporation, $\mathrm{mm} ; f(u)$ is the wind speed function and $e_{s}-e_{a}$ is $\mathrm{VPD}, \mathrm{kPa} ; e_{s}$ is the saturation vapor pressure at the temperature of water surface $\left(T_{s}\right)$ and $e_{a}$ is the vapor pressure at air temperature $\left(T_{a}\right.$, at $\left.2 \mathrm{~m}\right) . \mathrm{kPa}$ are empirically expressed as:

$$
\begin{gathered}
e_{S}\left(T_{S}\right)=0.611 \cdot \exp \left(\frac{17.27 T_{S}}{T_{S}+237.3}\right) \\
e_{a}=\frac{R H}{100} e\left(T_{S}\right)
\end{gathered}
$$

where $R H$ is relative humidity, \%, $T_{s}$ is evaporation surface temperature and $T_{a}$ is air temperature at $2 \mathrm{~m},{ }^{\circ} \mathrm{C}$.

Due to the lack of accessible surface temperature data, we use measured air temperature and assume that the temperature gradient between water surface and the measuring level of $T_{a}$ is zero [59,73], which implies $e_{s}\left(T_{s}\right)=e_{s}\left(T_{a}\right)$, and $e_{a}$ can be expressed empirically as the function of $T_{a}$, thus obtaining:

$$
e_{s}-e_{a}=g(R H) \cdot e_{a}=g(R H) \cdot h\left(T_{a}\right)
$$

where $g(R H)$ and $h\left(T_{a}\right)$ are function of relative humidity and air temperature, yielding:

$$
E_{0}=f(u) \cdot g(R H) \cdot h\left(T_{a}\right)
$$

Wind speed has a positive relationship with $E$ in transporting evaporated vapor to neighborhood, and the function can be expressed as:

$$
f(u)=\left(a+b \cdot u^{\alpha}\right)
$$

High $R H$ restrains the evaporation process as moisture accumulates in the air during the evaporation process, creating a negative relationship with $E$; high $T_{a}$ intensifies the escaping process of 
liquid water modular on the evaporation surface, so there is a positive relationship with evaporation. The $g(R H)$ and $h\left(T_{a}\right)$ function can be generalized as:

$$
\begin{gathered}
g(R H)=c-d \cdot R H^{\beta} \\
h\left(T_{a}\right)=m+n \cdot T_{a}^{\gamma}
\end{gathered}
$$

where $a, b, c, d, m$ and $n$ are undermined parameters and $\alpha, \beta, \gamma$ are often valued according to local synoptic conditions.

The power of $\alpha$ often ranges from 0.5 to 1.0, and according to the facts that measured wind speed data bears no good linear relationship with daily evaporation and the wind speed on EJL is quite high, we choose the value to be $0.5 ; \beta$ reflects the relative humidity's sensitivity regarding evaporation and ranges from 0.5 to 2.0 , so we choose the value to be 1.5 considering that atmospheric capacity of vapor restrains the process of lake evaporation in arid regions considerably; $\gamma$ ranges from 0.5 to 2.0 depending on different occasions, and considering that air temperature during the growing season ranges from $-10{ }^{\circ} \mathrm{C}$ to $40{ }^{\circ} \mathrm{C}$; the commonly used Equation (2) [74] can therefore be replaced by Equation (8) with the power of 1.0 for simplicity.

Thus, we generated a multivariate nonlinear evaporation model consisting of $T_{a}, u$ and $R H$. Parameterization and validation can be done with measured daily data from bankside weather station and floating evaporation pan.

\subsubsection{Inter-Comparisons of Evaporation Models}

After establishing and validating the evaporation model, we applied the deBruin-Keijman method [75] and Brutsaert-Stricker method [76] to EJL (Table 2) -both recognized for estimating daily open water evaporation with fine accuracy [56] — for comparison with our evaporation model.

Table 2. Selected evaporation method for comparison with the proposed model.

\begin{tabular}{cccc}
\hline Method & Reference & Equation & Developed for \\
\hline deBruin-Keijman & {$[75]$} & $E=86.4 \frac{\Delta}{0.85 \Delta+0.63 \gamma} \frac{R_{n}-Q x}{L \rho}$ & Daily evaporation \\
\hline Brutsaert-Stricker & {$[76]$} & $E=(2 \alpha-1) \frac{\Delta}{\Delta+\gamma} \frac{R_{n}-Q x}{L] \rho} \times 86.4-\frac{\gamma}{\Delta+\gamma} 0.26 \times\left(0.5+0.54 u_{2}\right)\left(e_{s}-e_{a}\right)$ & \\
\hline
\end{tabular}

Notes: $\Delta$ : slope of the saturated vapor pressure-temperature curve at mean air temperature $\left(\mathrm{Pa} \cdot{ }^{\circ} \mathrm{C}^{-1}\right) ; \gamma$ : psychrometric constant $\left(\mathrm{Pa} \cdot{ }^{\circ} \mathrm{C}^{-1}\right) ; R_{n}$ : net radiation $\left(\mathrm{W} \cdot \mathrm{m}^{-2}\right) ; Q_{x}$ : change in heat stored in the water body $\left(\mathrm{W} \cdot \mathrm{m}^{-2}\right) ; L$ : latent heat of vaporization $\left(\mathrm{MJ} \cdot \mathrm{kg}^{-1}\right) ; \rho$ : density of water $\left(1000 \mathrm{~kg} \cdot \mathrm{m}^{-3}\right)$; The calculation of $R_{n}$ follows Equations (9)-(15) [14].

$$
\begin{gathered}
R_{n}=R_{n L}-R_{n S} \\
R_{n L}=f \varepsilon^{\prime} \sigma(T+273.3)^{4} R_{n L}=f \varepsilon^{\prime} \sigma(T+273.3)^{4} \\
R_{n S}=(1-\alpha) R_{s} \\
f=\left(1.35 \frac{R_{s}}{R_{s o}}-0.35\right) \\
\varepsilon^{\prime}=0.34-0.14 \sqrt{e_{a}}
\end{gathered}
$$

where $\sigma$ is the Stephan-Boltzman constant $=4.933 \times 10^{-9}\left(\mathrm{MJ} / \mathrm{m}^{2} / \mathrm{K}^{4} /\right.$ day $), \alpha$ is reflection coefficient or albedo and for open water surface $\alpha=0.08, R_{S}$ is solar radiation and $R_{S O}$ is clear sky radiation $\left(\mathrm{W} \cdot \mathrm{m}^{-2}\right)$, calculated as

$$
\begin{gathered}
R_{S}=R_{A}\left(a+b \frac{n}{N}\right) \\
R_{S O}=\left(0.75+2 \times 10^{-5} \cdot Z\right) \cdot R_{A}
\end{gathered}
$$


For East Juyan Lake, the calibrated value of $a, b$ are 0.45 and $0.39, Z$ is elevation and $R_{A}$ is upper (outer limits of the atmosphere) solar radiation, $\mathrm{W} \cdot \mathrm{m}^{-2}$.

The other meteorological parameters that appear in the two methods are calculated as follows:

$$
\begin{gathered}
\lambda=2.501-\left(2.361 \times 10^{-3}\right) \cdot T_{a} \\
\gamma=0.0016286 \frac{P}{\lambda} \\
P=101.3\left(\frac{293-0.0065 Z}{293}\right)^{5.26} \\
\Delta=\frac{4098 e_{S}}{(T+237.3)^{2}}
\end{gathered}
$$

\section{Results}

\subsection{Time Series of East Juyan Lake's Daily Evaporation}

After quality control, we processed the water level data and obtained 239 daily evaporation data values (mainly from August to September in 2013, May to August in 2014 and April to September in 2015) (Figure 3).

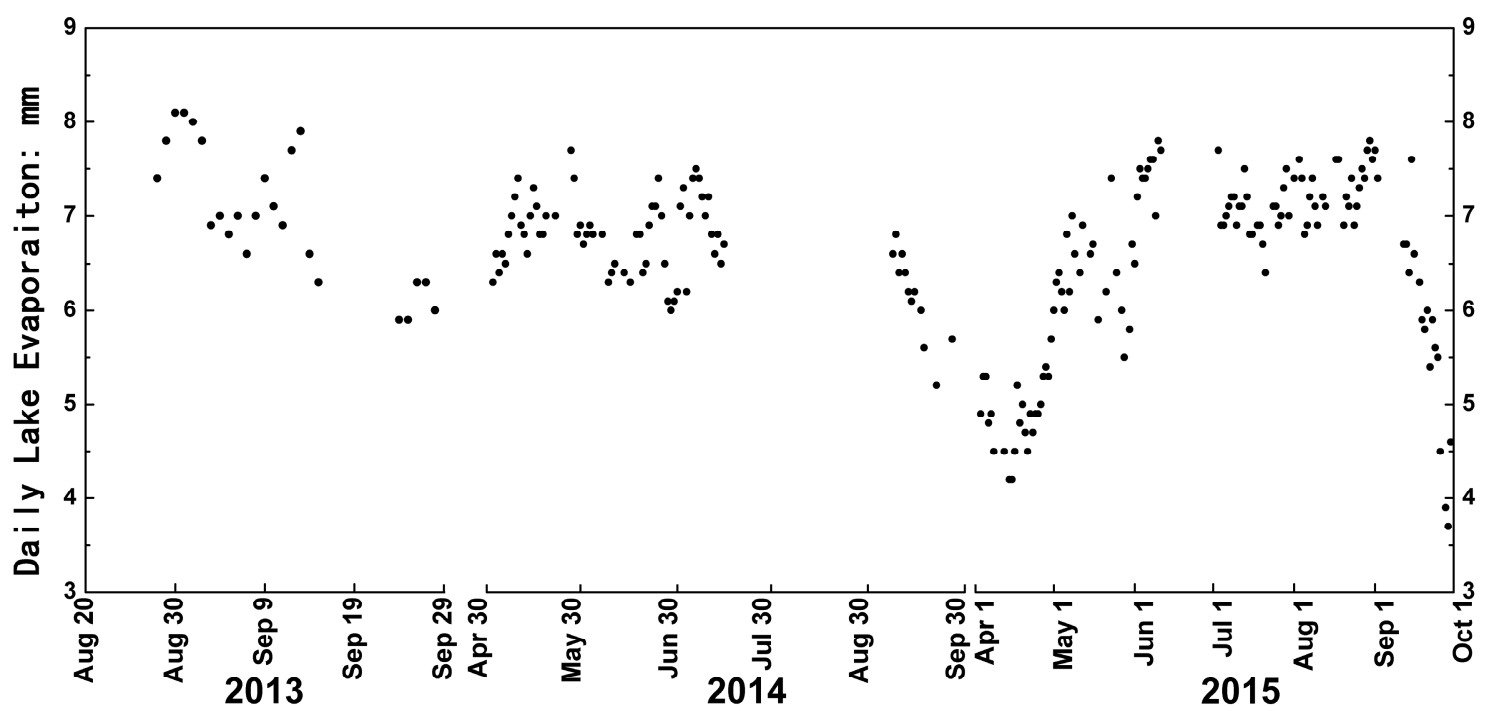

Figure 3. Time series of measured daily evaporation of EJL.

The daily evaporation data cover most days from April to September in 2013-2015, along with synoptic data measured at the EJL bankside weather station. The mean daily lake evaporation during the growing season is $6.5 \mathrm{~mm}$, the maximum and minimum daily evaporation are $8.1 \mathrm{~mm}$ (in August) and $3.7 \mathrm{~mm}$ (in September).

To obtain monthly evaporation of EJL, since data are occasionally unavailable in a month, we assume that if there are 15 or more measured daily evaporation scattering in each month, the mean daily evaporation of these available data is representative of the mean daily evaporation of this month, so the monthly evaporation can be calculated. Using the available data, we obtained the monthly lake evaporation of EJL (Table 3), from which we conclude that the mean total lake evaporation during annual growing season is $1183.3 \mathrm{~mm}$. 
Table 3. Actual monthly evaporation of EJL (mm).

\begin{tabular}{ccccccc}
\hline Year & April & May & June & July & August & September \\
\hline 2013 & $\backslash$ & $\backslash$ & $\backslash$ & $\backslash$ & $\backslash$ & 189.0 \\
2014 & $\backslash$ & 208.7 & 201 & 216.7 & 219.6 & 180.2 \\
2015 & 149.9 & 204.9 & 209.4 & 217.6 & 224.2 & 177.7 \\
\hline
\end{tabular}

\subsection{Daily Evaporation Model for EJL}

\subsubsection{Parameterization and Validation of the Proposed Model}

As described before, the semi-empirical daily lake evaporation for EJL is expressed as:

$$
E_{0}=f(u) \cdot g(R H) \cdot h\left(T_{a}\right)=\left(a+b \cdot u^{0.5}\right)\left(c-d \cdot R H^{1.5}\right)\left(m+n \cdot T_{a}\right)
$$

In deciding the parameters of $a, b, c, d, m$ and $n$, we used $u, R H$ and $T_{a}$ data measured at the EJL bankside weather station and floating E601 pan evaporation data of EJL from 2013 to 2014 (77 days of available data). After parameterization, the model can be expressed as:

$$
E_{0}=\left(0.0345+0.002 u^{0.5}\right)\left(42.6824-0.0122 R H^{1.5}\right)\left(2.66+0.08 \mathrm{~T}_{a}\right)
$$

Comparing with measured daily lake evaporation data, we see good accuracy in estimating daily evaporation of EJL using the proposed model, and the mean absolute error (MAE) is $0.52 \mathrm{~mm}$, root-mean-square error (RMSE) is $0.63 \mathrm{~mm}, R^{2}$ is 0.84 and the mean relative error (MRE) is $8.6 \%$ (Table 4).

Validation is also conducted. We used measured bankside synoptic data $(T, W$ and $R H)$ from April to August in 2015 to estimate the daily EJL evaporation with the proposed model, and compare with measured data from the floating E601 pan (114 days of available data) (Figure 4). Meanwhile, we compared the obtained monthly lake evaporation with estimated monthly evaporation, which is calculated from the daily evaporation estimation.

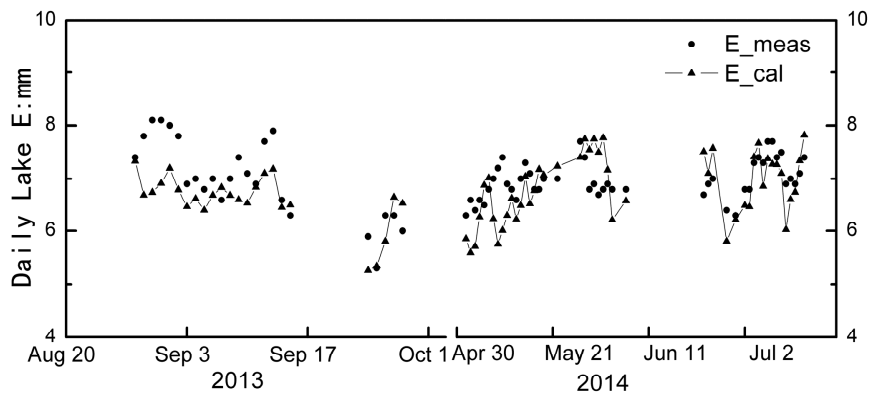

(a)

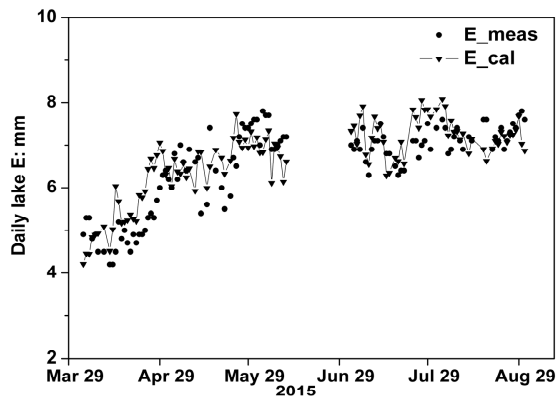

(b)

Figure 4. Calibration (a) and validation (b) of the daily evaporation model.

Table 4. Statistical index of model calibration (Cal.) and validation (Val.).

\begin{tabular}{ccccccccc}
\hline & & & & & \multicolumn{4}{c}{ Estimation Quality } \\
\cline { 7 - 9 } Index & $\boldsymbol{R}^{\mathbf{2}}$ & $\begin{array}{c}\text { MAE } \\
(\mathbf{m m})\end{array}$ & $\begin{array}{c}\text { RMSE } \\
(\mathbf{m m})\end{array}$ & MRE & $\begin{array}{c}\text { Within } \\
\mathbf{\pm 5 \%}\end{array}$ & $\begin{array}{c}\text { Within } \\
\pm \mathbf{1 0} \%\end{array}$ & $\begin{array}{c}\text { Within } \\
\mathbf{\pm 2 0} \%\end{array}$ & $\begin{array}{c}\text { Within } \\
\pm \mathbf{3 0} \%\end{array}$ \\
\hline Cal.-Daily E & 0.84 & 0.52 & 0.63 & $8.6 \%$ & $40 \%$ & $73 \%$ & $92 \%$ & $99 \%$ \\
Val.-Daily E & 0.80 & 0.56 & 0.69 & $9.5 \%$ & $44 \%$ & $72 \%$ & $88 \%$ & $96 \%$ \\
Val.-Monthly E & 0.94 & 6.10 & 8.10 & $3.0 \%$ & $78 \%$ & $100 \%$ & $/$ & $/$ \\
\hline
\end{tabular}




\subsubsection{Inter-Comparison of Evaporation Methods}

The deBruin-Keijman method and Brutsaert-Stricker method are believed to estimate daily open water evaporation with fine accuracy [56], so we applied them to calculate EJL's daily evaporation and compare the results with measured evaporation (Emea) (Figure 5 and Table 5).

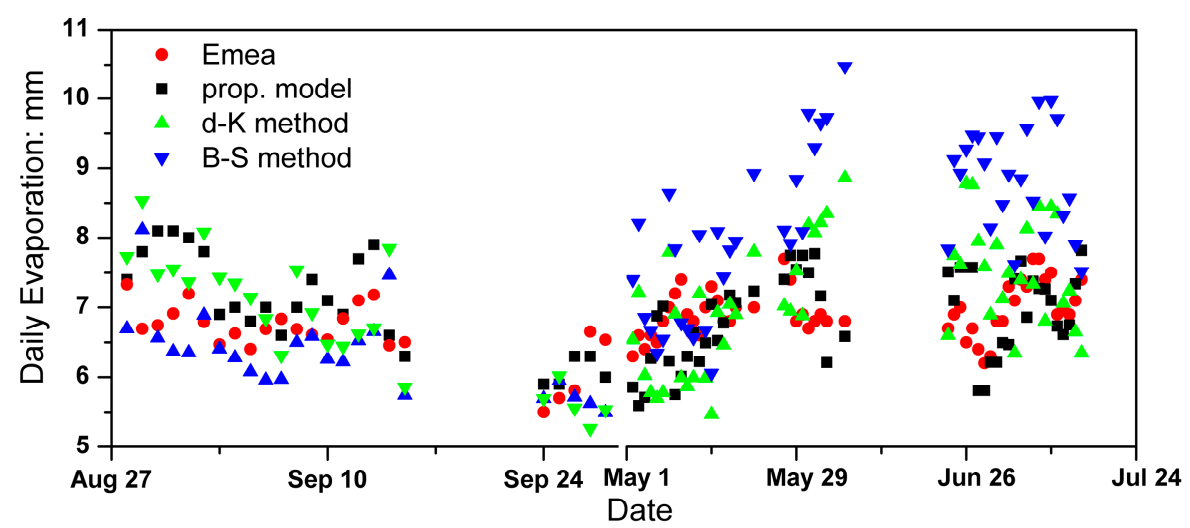

Figure 5. Comparisons of results by the three methods and measurement.

Table 5. Inter-comparison of statistical indexes of evaporation methods.

\begin{tabular}{ccccc}
\hline Method & $\boldsymbol{R}^{\mathbf{2}}$ & MAE (mm) & RMSE (mm) & MRE \\
\hline Proposed model & 0.84 & 0.52 & 0.63 & $8.6 \%$ \\
deBruin-Keijman & 0.62 & 0.81 & 0.96 & $10.9 \%$ \\
Brutsaert-Stricker & 0.55 & 1.20 & 1.51 & $17.7 \%$ \\
\hline
\end{tabular}

Our proposed model tends to yield better estimations of daily evaporation than the d-K and B-S methods, and d-K behaves better than B-S in this hyper-arid environment, with the MAE and RMSE being $0.81 \mathrm{~mm}$ and $0.96 \mathrm{~mm}$. In general, our proposed model can estimate daily evaporation of EJL with moderate accuracy, while the $\mathrm{d}-\mathrm{K}$ method tends to underestimate daily evaporation and the B-S method tends to overestimate (Figure 5).

\subsection{Estimation of EJL's Evaporation during 2002-2015}

Synoptic data $\left(u, R H\right.$ and $\left.T_{a}\right)$ are needed to estimate time series of EJL's evaporation from 2002 to 2015. Input synoptic data near the lake helps to estimate the evaporation more accurately [58]. However, the EJL bankside weather station was set up in 2013 and gathered only three years of synoptic data. Because the Ejina weather station is rich in accessible data (1959-2015), we expanded EJL's synoptic data series based on the correlativity (Table 6, Figure 6) of available data (2013-2015) from these two stations to get longer time series of synoptic data (2002-2015), with which we estimated EJL's daily evaporation.

Table 6. Correlativity between synoptic data at Ejina station and EJL station.

\begin{tabular}{ccc}
\hline Synoptic Factors & Correlativity & $\boldsymbol{R}^{\mathbf{2}}$ \\
\hline Air temperature & $Y=1.0256 X-0.8813$ & 0.991 \\
Wind speed & $\Upsilon=1.060 X+0.093$ & 0.683 \\
Relative humidity & $Y=0.939 X+7.340$ & 0.883 \\
\hline
\end{tabular}

Notes: In each expression, $X$ stands for data measured at Ejina weather station and $Y$ stands for EJL bankside data. 


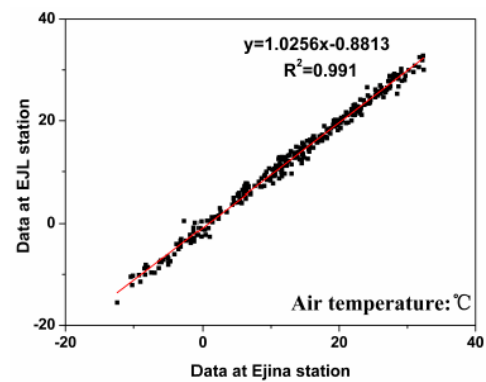

(a)

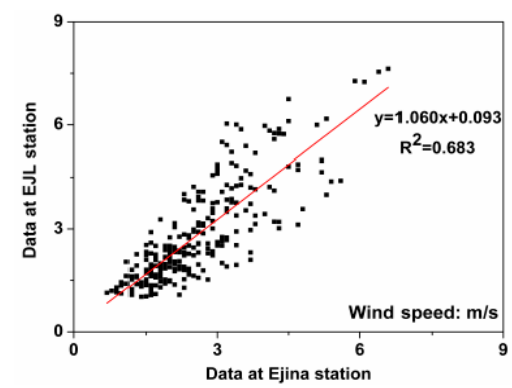

(b)

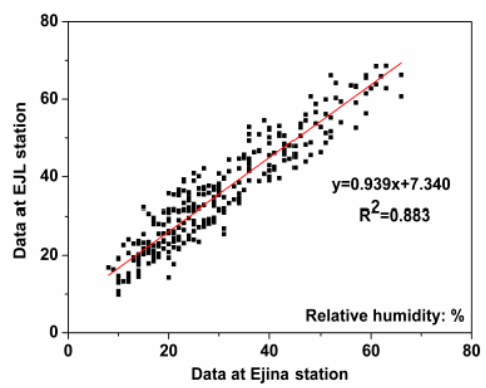

(c)

Figure 6. Correlativity of synoptic data between EJL and Ejina station. (a) $T_{a}$; (b) $u$; (c) $R H$.

Although the Ejina weather station is $60 \mathrm{~km}$ away from EJL, air temperature, wind speed and relative humidity measured at these two stations are well correlated and therefore a longer series of EJL bankside synoptic data can be obtained using the correlations. During 2002-2015, air temperature, mean annual wind speed and relative humidity have a trend of $0.013^{\circ} \mathrm{C} /$ year, $-0.036 \mathrm{~m} / \mathrm{s} /$ year and $-0.46 \%$ /year, respectively (Figure 7).

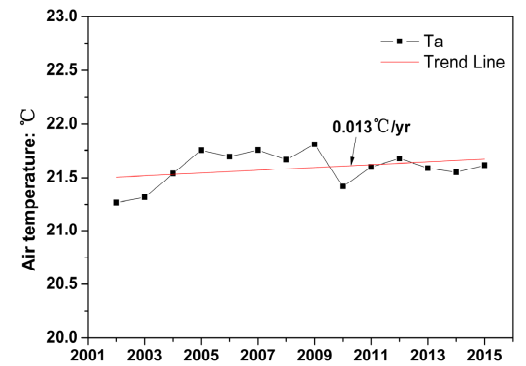

(a)

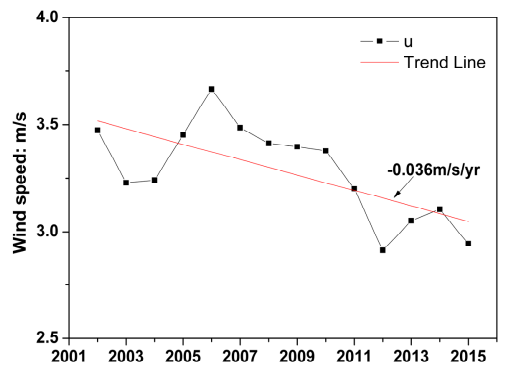

(b)

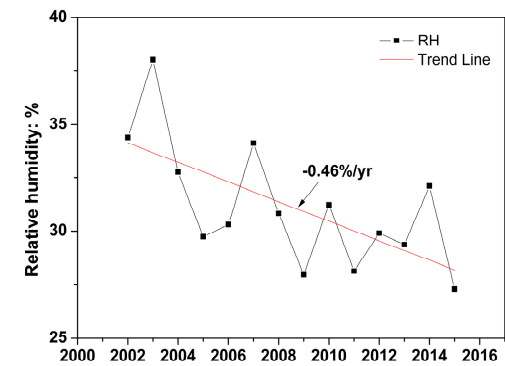

(c)

Figure 7. Mean annual variations of expanded governing synoptic factors of EJL. (a) $T_{a}$; (b) $u$; (c) $R H$.

For the growing season of 2002-2015 the estimated mean, maximum and minimum daily lake evaporation are $6.5 \mathrm{~mm}, 7.8 \mathrm{~mm}$ and $3.4 \mathrm{~mm}$; the estimated mean, maximum and minimum total lake evaporation are $1233.7 \mathrm{~mm}, 1190.7 \mathrm{~mm}$ (in 2003) and $1258.3 \mathrm{~mm}$ (in 2009), and there is an increasing trend in annual total evaporation of $0.83 \mathrm{~mm} /$ year. Generally, the maximum monthly lake evaporation appears in July or August, and the minimum monthly lake evaporation appears in April, which both accord with the temporal distribution of in situ measured monthly lake evaporation (Table 3).

\section{Discussion}

\subsection{Floating Pan Evaporation's Representativeness and Reliability}

During the growing season of 2013-2015, EJL's total measured evaporation was $1183.3 \mathrm{~mm}$. To obtain the annual open water evaporation, we had to consider the evaporation during the non-growing season (October to March, the next year), when it is the ice period and measuring instruments cannot work. Therefore, we converted the $\$ 20$ evaporation pan data from the Ejina weather station with the empirical conversion coefficient of 0.48 [77] to obtain the evaporation in this period. For 2013-2015, the mean converted total evaporation during the non-growing season was $\sim 288.0 \mathrm{~mm}$, making the mean annual open water evaporation $\left(\mathrm{ET}_{0}\right) 1471.3 \mathrm{~mm}$. Lake evaporation during the growing season took up $\sim 80 \%$ of the annual amount, while it was only $\sim 20 \%$ during the non-growing season. Lake evaporation during the growing season was in situ measured with high frequency and high reliability; although we could not neglect uncertainty of pan evaporation conversion method used to get the open water evaporation in non-growing season, its influence on the 
annual lake evaporation was quite small, considering its small portion $(20 \%)$ and the error of conversion method (within 15\% [78,79]). Consequently, we are confident that the combined annual evaporation, $1471.3 \mathrm{~mm}$, is quite convincing as the annual lake evaporation and standard representation of the lower Heihe River's annual $\mathrm{ET}_{0}$.

Open water evaporation, reference evapotranspiration and pan evaporation are used to represent regional $\mathrm{ET}_{0}[52,79-81]$. We converted $\mathrm{E} 601$ and $\$ 20$ pan evaporation at Ejina weather station with the conversion coefficient of 0.76 and 0.48 (referred to a research based on similar arid climate settings in Tarim River Basin [77]), the results demonstrating that the lower Heihe River's $\mathrm{ET}_{0}$ represented by pan evaporation was $1565.9 \mathrm{~mm}$. According to recent studies, calculated reference evapotranspiration in the lower Heihe River using the Food and Agriculture Organization (FAO) Penman-Monteith method were $1631 \mathrm{~mm}$ by Li [82] in 2013 and $1553 \mathrm{~mm}$ by Du [83] in 2016. Table 7 shows there is acceptable difference (less than 10\%) when using open water evaporation, E601 pan evaporation and reference evapotranspiration to represent $\mathrm{ET}_{0}$ of the lower Heihe River.

Table 7. Different method to represent lower Heihe River's annual $\mathrm{ET}_{0}$.

\begin{tabular}{ccc}
\hline Methods & ET $_{\mathbf{0}}(\mathbf{m m})$ & Difference with Open Water Evaporation Value \\
\hline Open water evaporation & 1471.3 & 0 \\
E601 pan evaporation & 1565.9 & $6.4 \%$ \\
Reference ET by Li [82] & 1631 & $9.8 \%$ \\
Reference ET by Du [83] & 1553 & $5.3 \%$ \\
\hline
\end{tabular}

\subsection{Model Sensitivity and Reliability}

The d-K and B-S methods tended to demonstrate larger uncertainty in estimating EJL's daily evaporation than the proposed model. The reason may be that these two methods have considered both aerodynamic and energy terms in evaporation, which requires more input variables, but in a data-sparse region like the Ejina Delta, some parameters such as $R_{n}, Q_{x}$ and VPD are unavailable, and hence have to be calculated using empirical methods, which increases the uncertainty due to these variables' high sensitivity $[84,85]$. On the contrary, the proposed model involves basic and accessible synoptic variables $\left(T_{a}, u\right.$ and $\left.R H\right)$ and is with moderate accuracy. The proposed model considered three governing synoptic factors as model inputs, and they accorded well with Granger and Hedstrom's finding that wind speed, air temperature and relative humidity are the most significant factors governing evaporation rate, after doing in situ evaporation measurement in three lakes [60]. Therefore, the proper model variables we selected could ensure the proposed model's reliability. Moreover, this model (Equation (20)), derived from the Dalton model, balances the simplicity of input data and accuracy of evaporation estimation well, and we are confident that, after parameterization with local input data, it is suitable for lakes in China's vast arid and data-sparse regions.

To find the most sensitive variables in the model, we analyzed their sensitivity coefficients, according to EJL's synoptic data, and estimated lake evaporation during the growing season of 2002-2015 (Figure 8$)$. The sensitivity coefficient $\left(S_{v}\right.$, dimensionless) vividly represents the changes in actual lake evaporation caused by any perturbation of the governing synoptic factors [86], and is defined as [87]:

$$
S_{v i}=\lim _{\Delta V i \rightarrow 0}\left(\frac{\Delta E / E}{\Delta V_{i} / V_{i}}\right)=\frac{\partial E}{\partial V_{i}} \cdot \frac{V_{i}}{E}
$$

where $\Delta V_{i}$ is the change of synoptic variables $\left(T_{a}, u\right.$ and $\left.R H\right)$, and $\Delta E$ is the change of evaporation.

For 2002-2015, the mean $S_{v}$ of $T_{a}, u$ and $R H$ are $0.67,0.51$ and -0.36 , respectively, indicating that air temperature has the highest sensitivity, followed by wind speed and relative humidity (negative). 


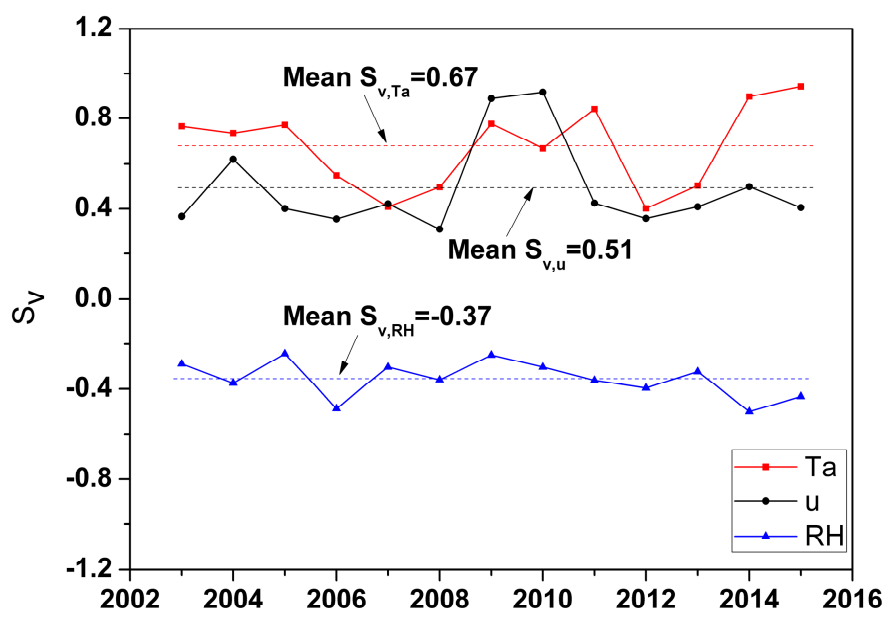

Figure 8. Sensitivity coefficients of each governing factors during 2002-2015.

In Granger and Hedstrom's research, wind speed was the most significant factor in lake evaporation [60]. The climatic settings of the two sites are different. Crean Lake is a small lake located in Canada with mild weather conditions (annual precipitation greater than $500 \mathrm{~mm}$ ), while EJL is located in a hyper-arid region with extreme weather conditions (annual precipitation of $36.6 \mathrm{~mm}$ ). The environmental factors ( $T_{a}, u$ and atmospheric turbulence) governing evaporation of water bodies can be substantially distinctive over small water bodies than over larger lakes [3,58]. Secondly, air temperature and wind speed are all very significant factors in open water evaporation; for EJL, a shallow lake (depth of $\sim 2 \mathrm{~m}$ ), compared with the deep Crean Lake (depth of $\sim 20 \mathrm{~m}$ ), the water is easily heated thoroughly (mean daily air temperature of $21.6^{\circ} \mathrm{C}$ during the growing season) and, with the help of high wind speed (mean value of $3.4 \mathrm{~m} / \mathrm{s}$ ) on the lake, air temperature shows even greater significance in lake evaporation than Crean Lake with its obvious temperature gradients of different water levels. Therefore, $T_{a}$ is the most sensitive factor, followed by $u$ in EJL.

\subsection{Complementary Relationship Theory's Adaptability in the Hyper-Arid Region}

The complementary relationship (CR) theory, used by Brutsaert to explain the evaporation paradox, suggests that in non-humid regions, the increase of temperature results in the increase of actual evaporation and the decrease of observed pan evaporation [50]. According to Figures 7a and $9 \mathrm{~b}$, the variation trends of $T_{a}$ and $E$ for the growing season of $2002-2015$ were $0.013{ }^{\circ} \mathrm{C} /$ year and $0.83 \mathrm{~mm} /$ year, indicating that there was an increasing trend of lake evaporation (representative of regional actual evaporation) along with the increase of air temperature, whereas, annual E601 pan evaporation (during the growing season) at Ejina weather station decreased over the last 14 years (Figure 10).

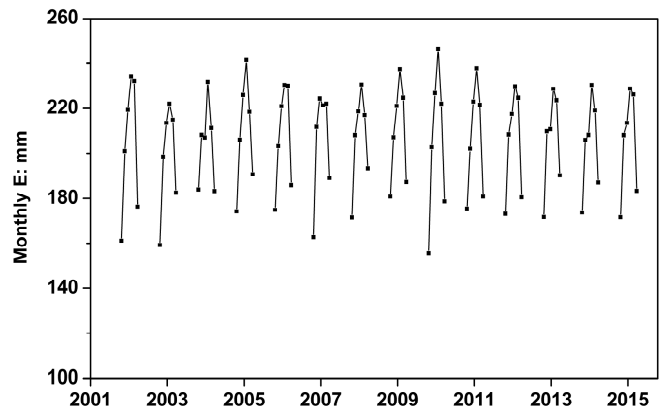

(a)

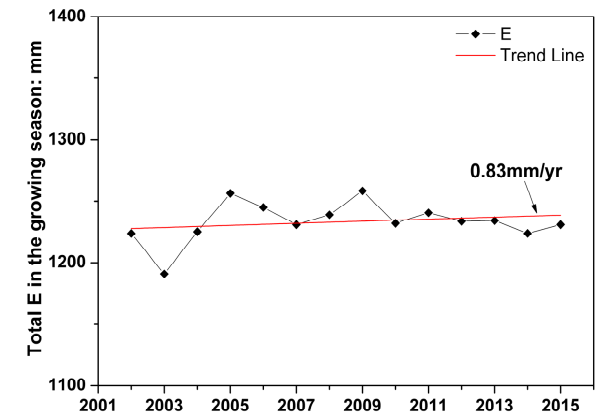

(b)

Figure 9. Estimated monthly (a) and growing season (b) lake evaporation in 2002-2015. 


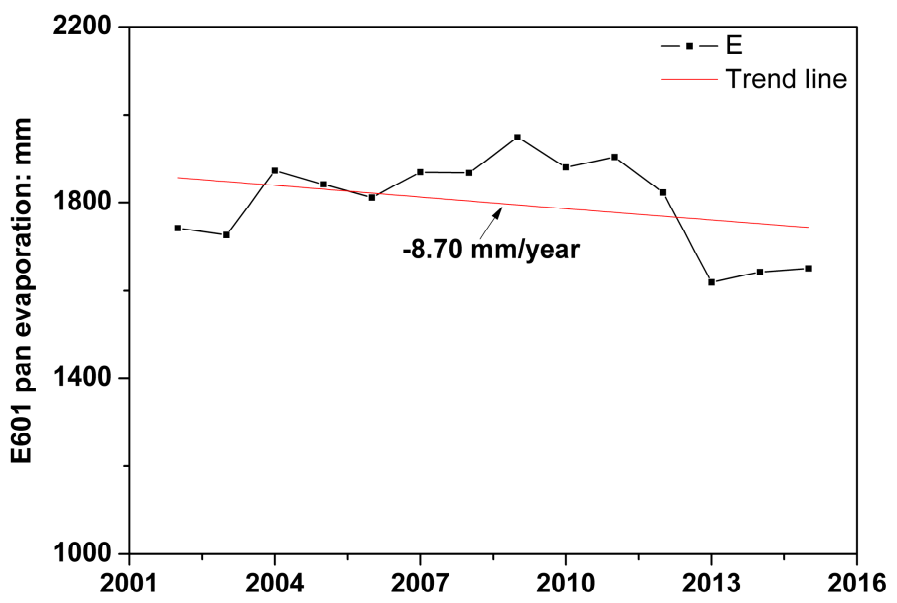

Figure 10. Observed annual E601 pan evaporation during 2002-2015.

The evaporation paradox suggests that with a warming climate, a declining rather than increasing trend of observed pan evaporation (i.e., apparent potential evaporation) during the past 50 years has been witnessed worldwide, especially in the Northern Hemisphere [50,88,89]. However, the "pan evaporation paradox" is a manifestation of the CR theory, as major declines of pan evaporation were witnessed in many sites in the US, Canada, Mexico, Iran, Thailand and India [90-96], many of which are in arid environmental settings. Similar proof for the evaporation paradox was reported in China's northwestern arid regions [33,97-99]. Set against a global background of the evaporation paradox, our research results—i.e., in situ measurements reliably estimated using our proposed model—indicate an increase of actual evaporation and decrease of observed pan evaporation in accordance with the available evidence; furthermore, it adds concrete proof of the existence of the evaporation paradox, as well as to the adaptability of the CR theory in China's hyper-arid region.

\section{Conclusions}

Quantifying lake evaporation is a theoretical and practical issue, especially in a hyper-arid region, as it offers important and reliable reference for relevant research. Through fine and fundamental evaporation measurement on East Juyan Lake (EJL) in the growing season of 2013-2015, EJL's measured mean total evaporation was $1183.3 \mathrm{~mm}$, and the maximum, minimum, mean daily lake evaporation were 8.1, 3.7, $6.5 \mathrm{~mm}$, respectively. The measured annual open water evaporation was $1471.3 \mathrm{~mm}$; along with E601 pan evaporation and the calculated reference evapotranspiration, these measurements well represent the lower Heihe River's ET $_{0}$ with little differences. The measurement of lake evaporation in growing season was solid and reliable, while measured data in non-growing season is lacking, so we converted the data from $\$ 20$ pan evaporation at Ejina weather station. Although such a conversion method has unneglectable errors, the results can still be favorable (less than $3 \%$ of uncertainty) since non-growing season evaporation only has a small portion ( $20 \%)$ of annual evaporation; therefore, the measured open water evaporation as potential evaporation $\left(\mathrm{ET}_{0}\right)$ is convincing. Moreover, this is an improvement to finding a more reliable and practical method to quantify lake evaporation (sublimation) during the non-growing season.

Derived from the Dalton model, parameterized and validated by in situ data, in addition to being compared with acknowledged evaporation models, the proposed daily lake evaporation model (Equation (21)) has the advantages not only of simplicity, reliability and accuracy, but also of potential utilization for other lakes in arid and data-sparse regions. Furthermore, apart from the governing synoptic factors considered in this study, lake area, water depth and water quality are also important factors in lake evaporation $[8,100,101]$ that could be used for modifying the proposed model for wider application in arid regions worldwide. 
Lastly, we utilized the model to obtain EJL's evaporation during 2002-2015; the mean growing season evaporation was $1233.7 \mathrm{~mm}$ ( $4 \%$ larger than measured value). The increasing trends of air temperature, actual lake evaporation and E601 pan evaporation proved the evaporation paradox's existence in this hyper-arid region and supported the complementary relationship (CR) theory's adaptability in this region. In conclusion, the results of this study gave us reliable $\mathrm{ET}_{0}$ reference for related researches in hyper-arid regions and deepened our understanding of the regional hydrological cycle and its response towards climate change.

Acknowledgments: The authors are thankful for the financial support of the National Natural Science Foundation of China (No. 41271049, No. 41371059) and research colleagues Enmin Liu, Zhiyong Wang, Kai Lu, Tianye Wang, Bei Li and Yafei Li, for their effort in performing the in situ measurements. Thanks for the academic advice from $\mathrm{Fu}$ Guobin, which is valuable and constructive. The local support from Ejina Bureau of Water Supplies is also highly appreciated.

Author Contributions: Xiao Liu, Ping Wang, Yichi Zhang and Chaoyang Du designed and performed the experiments; Liu Xiao analyzed the data. Under the supervision and guidance of Jingjie Yu and Ping Wang, Liu Xiao wrote the paper.

Conflicts of Interest: The authors declare no conflict of interest.

\section{References}

1. Betts, A.K.; Ball, J.H.; Beljaars, A.C.M.; Miller, M.J.; Viterbo, P.A. The land surface-atmosphere interaction: A review based on observational and global modeling perspectives. J. Geophys. Res. Atmos. 1996, 101, 7209-7225. [CrossRef]

2. Schlesinger, W.H.; Jasechko, S. Transpiration in the global water cycle. Agric. For. Meteorol. 2014, 189-190, 115-117. [CrossRef]

3. Assouline, S.; Tyler, S.W.; Tanny, J.; Cohen, S.; Bou-Zeid, E.; Parlange, M.B.; Katul, G.G. Evaporation from three water bodies of different sizes and climates: Measurements and scaling analysis. Adv. Water Resour. 2008, 31, 160-172. [CrossRef]

4. Sturrock, A.M.; Winter, T.C.; Rosenberry, D.O. Energy budget evaporation from Williams Lake: A closed lake in north central minnesota. Water Resour. Res. 1992, 28, 1605-1617. [CrossRef]

5. Jasechko, S.; Sharp, Z.D.; Gibson, J.J.; Birks, S.J.; Yi, Y.; Fawcett, P.J. Terrestrial water fluxes dominated by transpiration. Nature 2013, 496, 347-350. [CrossRef] [PubMed]

6. Winter, T.C.; Woo, M.-K. Hydrology of lakes and wetlands. In Surface Water Hydrology; Geological Society of America: Boulder, CO, USA, 1990; pp. 159-187.

7. Vercauteren, N.; Bou-Zeid, E.; Huwald, H.; Parlange, M.B.; Brutsaert, W. Estimation of wet surface evaporation from sensible heat flux measurements. Water Resour. Res. 2009, 45, 735-742. [CrossRef]

8. Brutsaert, W. Evaporation into the Atmosphere; Springer: Dordrecht, The Netherlands, 1982; pp. 3393-3398.

9. McMahon, T.A.; Peel, M.C.; Lowe, L.; Srikanthan, R.; McVicar, T.R. Estimating actual, potential, reference crop and pan evaporation using standard meteorological data: A pragmatic synthesis. Hydrol. Earth Syst. Sci. 2013, 17, 1331-1363. [CrossRef]

10. Abtew, W.; Melesse, A. Evaporation and Evapotranspiration: Measurements and Estimations; Abtew, W., Melesse, A., Eds.; Springer: Berlin, Germany, 2013.

11. Yang, X.; Ma, N.; Dong, J.; Zhu, B.; Xu, B.; Ma, Z.; Liu, J. Recharge to the Inter-Dune Lakes and holocene climatic changes in the Badain Jaran Desert, western China. Quat. Res. 2010, 73, 10-19. [CrossRef]

12. Si, J.; Feng, Q.; Yu, T.; Zhao, C. Inland river terminal lake preservation: Determining basin scale and the ecological water requirement. Environ. Earth Sci. 2015, 73, 3327-3334. [CrossRef]

13. Liao, J.; Wang, T.; Xue, X. Lake's evaporation in the Ejin basin since transfering water from the Heihe River. J. Desert Res. 2015, 35, 228-232, (In Chinese with English Abstract).

14. Shuttleworth, W.J.; Maidment, D.R. Evaporation. In Handbook of Hydrology; Maidment, D.R., Ed.; McGraw-Hill: New York, NY, USA, 1992; Chapter 504; pp. 505-572.

15. Lowe, L.D.; Webb, J.A.; Nathan, R.J.; Etchells, T.; Malano, H.M. Evaporation from water supply reservoirs: An assessment of uncertainty. J. Hydrol. 2009, 376, 261-274. [CrossRef]

16. McJannet, D.L.; Cook, F.J.; Burn, S. Comparison of techniques for estimating evaporation from an irrigation water storage. Water Resour. Res. 2013, 49, 1415-1428. [CrossRef] 
17. Winter, T.C. Uncertainties in estimating the water balance of lakes. JAWRA J. Am. Water Resour. Assoc. 1981, 17, 82-115. [CrossRef]

18. Zhao, L.; Xia, J.; Xu, C.-Y.; Wang, Z.; Sobkowiak, L.; Long, C. Evapotranspiration estimation methods in hydrological models. J. Geogr. Sci. 2013, 23, 359-369. [CrossRef]

19. Zhao, X.; Liu, Y. Lake fluctuation effectively regulates wetland evapotranspiration: A case study of the largest Freshwater Lake in China. Water 2014, 6, 2482-2500. [CrossRef]

20. Neuwirth, F. Experiences with Evaporation Pans at a Shallow Steppe-Lake in Austria. In Proceedings of the International Symposium on the Hydrology of Lakes, Helsinki, Finland, 23-27 July 1973; pp. 290-297.

21. Speranskaya, N.A. Changes in some elements of the water cycle in the easternmost part of the Baltic Sea Drainage Basin between 1945 and 2010. Oceanologia 2011, 53, 279-292. [CrossRef]

22. Lim, W.H.; Roderick, M.L.; Hobbins, M.T.; Wong, S.C.; Farquhar, G.D. The energy balance of a US Class A evaporation pan. Agric. For. Meteorol. 2013, 182, 314-331. [CrossRef]

23. Gangopadhyaya, M. Measurement and Estimation of Evaporation and Evapotranspiration; Report of a Working Group on evaporation Measurement of the Commission for Instruments and Methods of Observation; W.M.O.: Geneva, Switzerland, 1966.

24. Shuttleworth, W.J. Evapotranspiration measurement methods. Southwest Hydrol. 2008, 7, 22-23.

25. Hrvol', J.; Horecká, V. Actual Evapotranspiration, Potential Evapotranspirationand Evaporation from the ggi-3000 At Selected Stations of Slovakia. Available online: http://www.cbks.cz/sbornikStrecno06/ prispevky/PosterI._clanky/P1-5.pdf (accessed on 8 November 2016).

26. Riley, J.J. The heat balance of class a evaporation pan. Water Resour. Res. 1966, 2, 223-226. [CrossRef]

27. Jacobs, A.; Heusinkveld, B.; Lucassen, D. Temperature variation in a class a evaporation pan. J. Hydrol. 1998, 206, 75-83. [CrossRef]

28. Masoner, J.R.; Stannard, D.I.; Christenson, S.C. Differences in evaporation between a floating pan and class a pan on land. JAWRA J. Am. Water Resour. Assoc. 2008, 44, 552-561. [CrossRef]

29. Fu, G.; Liu, C.; Chen, S.; Hong, J. Investigating the conversion coefficients for free water surface evaporation of different evaporation pans. Hydrol. Process. 2004, 18, 2247-2262. [CrossRef]

30. Li, Z.; Chen, Y.; Shen, Y.; Liu, Y.; Zhang, S. Analysis of changing pan evaporation in the arid region of northwest China (EI). Water Resour. Res. 2013, 49, 2205-2212. [CrossRef]

31. Abtew, W.; Obeysekera, J.; Iricanin, N. Pan evaporation and potential evapotranspiration trends in south Florida. Hydrol. Process. 2011, 25, 958-969. [CrossRef]

32. Chen, D.; Gao, G.; Xu, C.-Y.; Guo, J.; Ren, G. Comparison of the thornthwaite method and pan data with the standard Penman-Monteith estimates of reference evapotranspiration in China. Clim. Res. 2005, 28, 123-132. [CrossRef]

33. Shen, Y.; Liu, C.; Liu, M.; Yan, Z.; Tian, C. Change in pan evaporation over the past 50 years in the arid region of China. Hydrol. Process. 2010, 24, 225-231. [CrossRef]

34. Xu, C.Y.; Gong, L.; Jiang, T.; Chen, D.; Singh, V.P. Analysis of spatial distribution and temporal trend of reference evapotranspiration and pan evaporation in Changjiang (Yangtze River) catchment. J. Hydrol. 2006, 327, 81-93. [CrossRef]

35. Li, S.; Wang, Q.; Li, L. Interdecadal variations of pan-evaporation at the southern and northern slopes of the Tianshan Mountains, China. J. Arid Land 2016, 8, 832-845. [CrossRef]

36. Fu, G.; Charles, S.P.; Yu, J. A critical overview of pan evaporation trends over the last 50 years. Clim. Chang. 2009, 97, 193-214. [CrossRef]

37. Nordbo, A.; Launiainen, S.; Mammarella, I.; Leppäranta, M.; Huotari, J.; Ojala, A.; Vesala, T. Long-term energy flux measurements and energy balance over a small boreal lake using eddy covariance technique. J. Geophys. Res. Atmos. 2011, 116, 3-25. [CrossRef]

38. Blanken, P.D.; Rouse, W.R.; Culf, A.D.; Chris, S.; Dale, B.L.; Jasper, J.N.; Bob, K.; Schertzer, W.M.; Philip, M.; Diana, V. Eddy covariance measurements of evaporation from great Slave Lake, Northwest Territories, Canada. Water Resour. Res. 2000, 36, 1069-1077. [CrossRef]

39. Tanny, J.; Cohen, S.; Assouline, S.; Lange, F.; Grava, A.; Berger, D.; Teltch, B.; Parlange, M.B. Evaporation from a small water reservoir: Direct measurements and estimates. J. Hydrol. 2010, 351, 218-229. [CrossRef]

40. Liu, H.; Feng, J.; Sun, J.; Wang, L.; Xu, A. Eddy covariance measurements of water vapor and $\mathrm{CO}_{2}$ fluxes above the Erhai Lake. Sci. China Earth Sci. 2015, 58, 317-328. [CrossRef] 
41. Ma, N.; Szilagyi, J.; Niu, G.Y.; Zhang, Y.; Zhang, T.; Wang, B.; Wu, Y. Evaporation variability of Nam Co Lake in the Tibetan Plateau and its role in recent rapid lake expansion. J. Hydrol. 2016, 537, 27-35. [CrossRef]

42. Ning, M.; Zhang, Y.; Xu, C.Y.; Jozsef, S. Modeling actual evapotranspiration with routine meteorological variables in the data-scarce region of the Tibetan Plateau: Comparisons and implications. J. Geophys. Res. Biogeosci. 2015, 120, 1638-1657.

43. Liu, H.; Zhang, Y.; Liu, S.; Jiang, H.; Sheng, L.; Williams, Q.L. Eddy covariance measurements of surface energy budget and evaporation in a cool season over southern open water in Mississippi. J. Geophys. Res. 1993, 114, 83-84. [CrossRef]

44. Li, Z.; Lyu, S.; Ao, Y.; Wen, L.; Zhao, L.; Wang, S. Long-term energy flux and radiation balance observations over Lake Ngoring, Tibetan Plateau. Atmos. Res. 2015, 155, 13-25. [CrossRef]

45. Dalton, J. Experimental essays on evaporation. Manch. Lit. Philos. Soc. 1802, 5, 536-602.

46. Bowen, I.S. The ratio of heat losses by conduction and by evaporation from any water surface. Phys. Rev. 1926, 27, 779-787. [CrossRef]

47. Penman, H.L. Natural evaporation from open water, hare soil and grass. Proc. R. Soc. Lond. 1948, 193, 120-145. [CrossRef]

48. Priestley, C.; Taylor, R. On the assessment of surface heat flux and evaporation using large-scale parameters. Mon. Weather Rev. 1972, 100, 81-92. [CrossRef]

49. Shuttleworth, W.J. Evaporation Models in the Global Water Budget; Springer: Dordrecht, The Netherlands, 1983; pp. 147-171.

50. Brutsaert, W.; Parlange, M.B. Hydrologic cycle explains the evaporation paradox. Nature 1998, 396, doi:10.1038/23845. [CrossRef]

51. Szilagyi, J.; Jozsa, J. New findings about the complementary relationship-based evaporation estimation methods. J. Hydrol. 2008, 354, 171-186. [CrossRef]

52. Kahler, D.M.; Brutsaert, W. Complementary relationship between daily evaporation in the environment and pan evaporation. Water Resour. Res. 2006, 42, 648-648. [CrossRef]

53. Shilo, E.; Ziv, B.; Shamir, E.; Rimmer, A. Evaporation from Lake Kinneret, Israel, during hot summer days. J. Hydrol. 2015, 528, 264-275. [CrossRef]

54. Singh, R.; Senay, G. Comparison of four different energy balance models for estimating evapotranspiration in the midwestern United States. Water 2016, 8, 9. [CrossRef]

55. Winter, T.C.; Rosenberry, D.O.; Sturrock, A.M. Evaluation of 11 equations for determining evaporation for a small lake in the north central United States. Water Resour. Res. 1995, 31, 983-993. [CrossRef]

56. Rosenberry, D.O.; Winter, T.C.; Buso, D.C.; Likens, G.E. Comparison of 15 evaporation methods applied to a small mountain lake in the northeastern USA. J. Hydrol. 2007, 340, 149-166. [CrossRef]

57. Masoner, J.R.; Stannard, D.I. A comparison of methods for estimating open-water evaporation in small wetlands. Wetlands 2010, 30, 513-524. [CrossRef]

58. Mcgloin, R.; Mcgowan, H.; Mcjannet, D.; Burn, S. Modelling sub-daily latent heat fluxes from a small reservoir. J. Hydrol. 2014, 519, 2301-2311. [CrossRef]

59. Valiantzas, J.D. Simplified versions for the penman evaporation equation using routine weather data. J. Hydrol. 2006, 331, 690-702. [CrossRef]

60. Granger, R.J.; Hedstrom, N. Modelling hourly rates of evaporation from small lakes. Hydrol. Earth Syst. Sci. 2011, 15, 267-277. [CrossRef]

61. Nash, D.J.; Middleton, N.; Thomas, D. World Atlas of Desertification; United Nations Environment Programme: London, UK, 1997.

62. Xie, Q. Regional Hydrogeological Survey Report of the People's Republic of China (1:200,000): Ejina k-47-[24][R]; Water Conservancy Department of Inner Mongolia: Hohhot City, China, 1980. (In Chinese)

63. Wang, P.; Zhang, Y.; Yu, J.; Fu, G.; Fei, A. Vegetation dynamics induced by groundwater fluctuations in the lower Heihe River Basin, northwestern China. J. Plant Ecol. 2011, 4, 77-90. [CrossRef]

64. Wang, P.; Yu, J.; Pozdniakov, S.P.; Grinevsky, S.O.; Liu, C. Shallow groundwater dynamics and its driving forces in extremely arid areas: A case study of the lower Heihe River in northwestern China. Hydrol. Process. 2014, 28, 1539-1553. [CrossRef]

65. Xi, H.; Feng, Q.; Si, J.; Chang, Z.; Cao, S. Impacts of river recharge on groundwater level and hydrochemistry in the lower reaches of Heihe River Watershed, northwestern China. Hydrogeol. J. 2009, 18, 791-801. [CrossRef] 
66. Liu, X.; Yichi, Z.; Du, C.; Yu, J. The current land use situation and characteristics of temporal and spatial distribution of its evapotranspiration in Ejina delta. South-to-North Water Transf. Water Sci. Technol. 2015, 4, 609-613. (In Chinese with English Abstract)

67. Jiang, X.; Liu, C. The influence of water regulation on vegetation in the lower Heihe River. J. Geogr. Sci. 2010, 20, 701-711. [CrossRef]

68. Zhang, Y.; Yu, J.; Wang, P.; Fu, G. Vegetation responses to integrated water management in the Ejina Basin, northwest China. Hydrol. Process. 2011, 25, 3448-3461. [CrossRef]

69. Guo, Q.; Qi, F.; Li, J. Environmental changes after ecological water conveyance in the lower reaches of Heihe River, northwest China. Environ. Geol. 2009, 58, 1387-1396. [CrossRef]

70. Qi, S.; Luo, F. Environmental degradation problems in the Heihe River Basin, northwest China. Water Environ. J. 2007, 21, 142-148. [CrossRef]

71. World Meteorological Organization (WMO). Instruments and Methods of Observation: Measurement of Evaporation; WMO-No. 8; WMO: Geneva, Switzerland, 2010; Chapter 10.

72. Singh, V.P.; Xu, C.Y. Evaluation and generalization of 13 mass-transfer equations for determining free water evaporation. Hydrol. Process. 1997, 11, 311-323. [CrossRef]

73. Jensen, M.E.; Burman, R.D.; Allen, R.G. Evapotranspiration and Irrigation Water Requirements: A Manual; American Society of Civil Engineers: New York, NY, USA, 2015.

74. Allen, R.G.; Pereira, L.S.; Raes, D.; Smith, M. Crop Evapotranspiration-Guidelines for Computing Crop Water Requirements-FAO Irrigation and Drainage Paper 56; FAO: Rome, Italy, 1998.

75. De Bruin, H.; Keijman, J. The priestley-taylor evaporation model applied to a large, shallow lake in The Netherlands. J. Appl. Meteorol. 1979, 18, 898-903. [CrossRef]

76. Brutsaert, W.; Stricker, H. An advection-aridity approach to estimate actual regional evapotranspiration. Water Resour. Res. 1979, 15, 443-450. [CrossRef]

77. Hu, S.; Tian, C.; Song, Y.; Chen, B.; Wang, F. Conversion coefficient of water surface evaporation in Tarim River Basin. J. Desert Res. 2005, 25, 649-651, (Chinese with English Abstract).

78. Lee, K.H.; Cho, H.Y. Simple method for estimating pan coefficients: Conversion of pan evaporation to reference evapotranspiration. J. Irrig. Drain. Eng. 2012, 138, 98-103. [CrossRef]

79. Trajkovic, S.; Kolakovic, S. Comparison of simplified pan-based equations for estimating reference evapotranspiration. J. Irrig. Drain. Eng. 2010, 136, 137-140. [CrossRef]

80. Elsawwaf, M.; Willems, P.; Pagano, A.; Berlamont, J. Evaporation estimates from Nasser Lake, Egypt, based on three floating station data and bowen ratio energy budget. Theor. Appl. Climatol. 2009, 100, $439-465$. [CrossRef]

81. Sumner, D.M.; Jacobs, J.M. Utility of Penman-Monteith, Priestley-Taylor, reference evapotranspiration, and pan evaporation methods to estimate pasture evapotranspiration. J. Hydrol. 2005, 308, 81-104. [CrossRef]

82. Li, Z.; Li, Z.; Xu, Z.; Zhou, X. Temporal variations of reference evapotranspiration in Heihe River Basin of China. Hydrol. Res. 2013, 44, 904-916. [CrossRef]

83. Du, C.; Yu, J.; Wang, P.; Zhang, Y. Reference evapotranspiration changes: Sensitivities to and contributions of meteorological factors in the Heihe River Basin of Northwestern China (1961-2014). Adv. Meteorol. 2016, 2016, 4143580. [CrossRef]

84. Elsawwaf, M.; Willems, P.; Feyen, J. Assessment of the sensitivity and prediction uncertainty of evaporation models applied to Nasser Lake, Egypt. J. Hydrol. 2010, 395, 11-22. [CrossRef]

85. Wang, W.; Xiao, W.; Cao, C.; Gao, Z.; Hu, Z.; Liu, S.; Shen, S.; Wang, L.; Xiao, Q.; Xu, J. Temporal and spatial variations in radiation and energy balance across a large freshwater lake in China. J. Hydrol. 2014, 511, 811-824. [CrossRef]

86. Gong, L.; Xu, C.Y.; Chen, D.; Halldin, S.; Chen, Y.D. Sensitivity of the Penman-Monteith reference evapotranspiration to key climatic variables in the Changjiang (Yangtze River) basin. J. Hydrol. 2006, 329, 620-629. [CrossRef]

87. Beven, K. A sensitivity analysis of the penman-monteith actual evapotranspiration estimates. J. Hydrol. 1979, 44, 169-190. [CrossRef]

88. Roderick, M.L.; Farquhar, G.D. The cause of decreased pan evaporation over the past 50 years. Science 2002, 298, 1410-1411. [PubMed]

89. Ohmura, A.; Wild, M. Is the hydrological cycle accelerating? Science 2002, 298, 1345-1346. [CrossRef] [PubMed] 
90. Mcvicar, T.R.; Roderick, M.L.; Donohue, R.J.; Li, L.T.; Niel, T.G.V.; Thomas, A.; Grieser, J.; Jhajharia, D.; Himri, Y.; Mahowald, N.M. Global review and synthesis of trends in observed terrestrial near-surface wind speeds: Implications for evaporation. J. Hydrol. 2012, 416-417, 182-205. [CrossRef]

91. Hobbins, M.T.; Ramírez, J.A.; Brown, T.C. Trends in pan evaporation and actual evapotranspiration across the conterminous U.S.: Paradoxical or complementary? Geophys. Res. Lett. 2004, 31, 405-407. [CrossRef]

92. Burn, D.H.; Hesch, N.M. Trends in evaporation for the Canadian Prairies. J. Hydrol. 2007, 336, 61-73. [CrossRef]

93. Blanco-Macías, F.; Valdez-Cepeda, R.D.; Magallanes-Quintanar, R. Pan evaporation analysis in central Mxico: Trends, self-affinity and important frequencies. Int. J. Phys. Sci. 2011, 6, 540-549.

94. Salarijazi, M. Assessment of pan evaporation changes in south western Iran. Afr. J. Agric. Res. 2013, 8, 1449-1456.

95. Tebakari, T.; Yoshitani, J.; Suvanpimol, C. Time-space trend analysis in pan evaporation over kingdom of Thailand. J. Hydrol. Eng. 2005, 10, 205-215. [CrossRef]

96. Jhajharia, D.; Kumar, R.; Singh, V.P.; Choudhary, R.R. Searching evidence for the existence of evaporation paradox in arid environments of northwest India. Glob. Nest J. 2014, 16, 1-9.

97. Liu, X.; Luo, Y.; Zhang, D.; Zhang, M.; Liu, C. Recent changes in pan-evaporation dynamics in China. Geophys. Res. Lett. 2011, 38, 142-154. [CrossRef]

98. Wang, Z.; Yu, J.; Denghua, A. Effects of climatic variables on pan evaporation in Ejina delta in the recent 50 years. South-to-North. Water Transf. Water Sci. Technol. 2013, 3, 1-5. (In Chinese with English Abstract)

99. Liu, M.; Shen, Y.; Zeng, Y.; Liu, C. Trend in pan evaporation and its attribution over the past 50 years in China. J. Geogr. Sci. 2010, 20, 557-568. [CrossRef]

100. Semiz, G.D.; Akşit, C.; Akşit, C. Water quality, surface area, evaporation and precipitation of Lake Burdur. J. Food Agric. Environ. 2013, 11, 751-753.

101. Verburg, P.; Hecky, R.E. Wind patterns, evaporation, and related physical variables in Lake Tanganyika, East Africa. J. Gt. Lakes Res. 2003, 29, 48-61. [CrossRef]

(C) 2016 by the authors; licensee MDPI, Basel, Switzerland. This article is an open access article distributed under the terms and conditions of the Creative Commons Attribution (CC-BY) license (http://creativecommons.org/licenses/by/4.0/). 